Res Pública Revista de Historia de las Ideas Políticas

ISSN: 1131-558X

http://dx.doi.org/10.5209/rpub.67119

\title{
Judaísmo, filosofia e historia. Acerca de la lectura arendtiana de Lessing, Mendelssohn y Herder en los tempranos años 30
}

\author{
Laura Arese ${ }^{1}$ \\ Recibido: 19 de diciembre de 2019 / Aceptado: 08 de junio de 2020
}

Resumen. El objetivo de este artículo es reconstruir la lectura que realiza Hannah Arendt de Lessing, Mendelssohn y Herder en relación a sus abordajes de la cuestión judía, a comienzos de los años 30. El telón de fondo de esta lectura es la dificultad que, a juicio de la autora, evidencian los judíos europeos desde la emancipación para alcanzar una perspectiva política sobre su propia historia. Sostenemos que, en su lectura de estos filósofos, Arendt identifica una tensión entre razón e historia, cuya radicalización da como resultado una idea de razón incapaz de acoger la dimensión histórica de los pueblos en clave política. La consecuencia de esto es la frustración de las promesas políticas de la emancipación judía, y la afirmación de un modelo de asimilación desembarazado de la historia. Sin embargo, sostendremos también que, para Arendt, la Ilustración representada por Lessing y el romanticismo que encarna Herder, no se inscriben en una misma línea de continuidad. Por el contrario, Arendt encuentra tempranamente en Lessing un legado que conserva valor para el presente.

Palabras claves: historia; razón; política; judaísmo; Arendt.

\section{[en] Judaism, Philosophy and History. On Hannah Arendt's Reading of Lessing, Mendelssohn and Herder in the Early 1930s}

\begin{abstract}
The paper aims to reconstruct Hannah Arendt's reading of Lessing, Mendelssohn and Herder, concerning their approaches to the Jewish question, in the early 1930s. The background of this reading is the difficulty that, according to the author, European Jews demonstrate since emancipation to reach a political perspective on their own history. The paper claims that, in her reading of these philosophers, Arendt identifies a tension between reason and history, whose radicalization results in an idea of reason unable to grasp the historical dimension of peoples from a political point of view. The consequence is the frustration of the political promises of Jewish emancipation, and the triumph of an ahistorical assimilation's model. However, it will be argued that, for Arendt, the Enlightenment represented by Lessing and the romanticism that Herder embodies, do not fall along the same line of continuity. On the contrary, Arendt finds in Lessing a legacy which remains valuable for the present. Keywords: History; Reason; Politics; Judaism; Arendt.
\end{abstract}

Sumario. 1. Introducción. 2. La cuestión judía en la tradición alemana: de Lessing a Herder. 3. Ilustración y romanticismo frente a la historia: un balance. 4. Consideraciones finales. 5. Bibliografía.

Cómo citar: Arese, L. (2020). Judaísmo, filosofía e historia. Acerca de la lectura arendtiana de Lessing, Mendelssohn y Herder en los tempranos años 30. Res Pública. Revista de Historia de las Ideas Políticas, 23(1), 217-229.

\section{Introducción}

A comienzos de la década del 30, urgida por la escalada antisemita e influenciada por su reciente acercamiento al sionismo, Hannah Arendt comienza una indagación histórico-filosófica en torno a la peligrosa situación política en la que se encontraban los judíos europeos. Parte de su preocupación gira en torno a una idea que concibe durante estos años y no abandonará jamás: cierto déficit de sentido histórico entre los judíos, esto es, cierta dificul- tad para apropiarse de su propio pasado desde una perspectiva política, que considera recurrente entre ellos, ha contribuido a socavar sus posibilidades de acción y a afirmarlos en la impotencia. La autora no considera esta dificultad y desinterés, un rasgo del judaísmo como tal, sino un modo adquirido cuyas raíces en el tiempo se propone indagar. La indagación que emprende entonces conduce a los orígenes del proceso de asimilación, esto es, los años de la emancipación judía, especialmente la alemana ${ }^{2}$.

\footnotetext{
Universidad Nacional de Córdoba (Argentina)
}

arese.laura@gmail.com

Cuando decimos "emancipación" en este artículo nos referimos al proceso por el cual se reconoció paulatinamente igualdad de derechos a los judíos en distintos países de Europa, entre fines del siglo XVIII y a lo largo del XIX. A Arendt le interesa especialmente el contexto alemán, cuyo momento clave es el "Edicto de Emancipación" prusiano de 1812. Una indagación de este proceso y su importancia, tanto para la asimilación como para la "modernidad judía", en general, se puede consultar en E. Traverso, El final de la modernidad judia: historia de un giro conservador, Buenos Aires, Fondo de Cultura Económica, 2014, especialmente el capítulo II. 
El objetivo de este artículo es reconstruir un momento clave de esta indagación. Nos interesa recuperar las lecturas que la autora realiza de Lessing, Mendelssohn y Herder, tomando como eje sus abordajes de la cuestión judía. Centrándonos en "La Ilustración y la cuestión judía" , nos interesa recuperar cómo, en el recorrido que traza a través de estos autores, Arendt identifica un problema que le permite echar luz sobre las raíces en la tradición filosófica de esta disposición problemática de los judíos frente a su historia. El problema consiste en una tensión irresuelta, de origen ilustrado, entre razón e historia. En un arco que va de Lessing a Herder, esta tensión se radicaliza y da como resultado una idea de razón incapaz de acoger la dimensión histórica de los pueblos, en clave política. La consecuencia de esto es la frustración de las promesas políticas de la emancipación judía, y la afirmación de un modelo de asimilación desembarazado de la historia. Sin embargo, sostendremos también, en discusión con quienes ven en Arendt una crítica radical de la tradición ilustrada, que, para la autora, la Ilustración representada por Lessing y el romanticismo que encarna Herder, no se inscriben en una misma línea de continuidad. Por el contrario, Arendt recupera de Lessing un legado valioso para su propio presente: la reivindicación de cierta "autonomía de la razón frente a la historia".

El análisis pretende ofrecer una contribución al vasto campo de discusión que, con especial fuerza desde la publicación de los así llamados "escritos judíos", busca esclarecer los complejos vínculos entre la crítica de Arendt a la tradición filosófica y su confrontación, no sólo personal y política, sino también filosófica, con el judaísmo. Con esta intención, y con base en lo desarrollado, hacia el final discutiremos ciertas interpretaciones que ubican a Arendt junto a un espectro de pensadores que emprenden una crítica judía, o desde el judaísmo, al universalismo de la Ilustración. Sin desestimar afinidades, nos interesa distinguir una singularidad de la crítica arendtiana a la tradición filosófica, que estas interpretaciones diluyen.

\section{La cuestión judía en la tradición alemana: de Lessing a Herder}

Rahel Varnhagen ${ }^{5}$ contiene una profunda crítica al proyecto de emancipación judía y al proceso de asimilación

H. Arendt, "La Ilustración y la cuestión judía”, en J. Kohn y R. H. Feldman (eds.), Escritos judios, trad. M. Cancel, R. S. Carbó, V. Gómez Ibáñez y E. Cañas, Barcelona, Paidós, 2009, pp. 79-96.

4 La primera compilación que reunió estos escritos fue H. Arendt, The Jew as a Pariah: Jewish Identity and Politics in the Modern Age, en R. H. Feldman (ed.), Nueva York, Grove Press, 1978. Luego se publicó The Jewish Writings, J. Kohn y R. H. Feldman (eds.), Nueva York, Schocken Books, 2007, que incorpora numerosos nuevos artículos. Citamos aquí la traducción española de esta obra: Escritos judios, op. cit.

$5 \quad$ H. Arendt, Rahel Varnhagen: vida de una mujer judia, trad. D. Najmías, Barcelona, Lumen, 2000. Arendt consideraba el libro concluido en 1933, pero, según relata a Jaspers, durante su exilio en París y a raíz de intercambios con Walter Benjamin y Henrich Blücher, decide agregarle los dos últimos capítulos, que concluye en 1938. Cf. H. Arendt y K. Jaspers, Hannah Arendt/Karl Jaspers: Briefwechsel 1926-1969, en L. Köhler y H. Saner (eds.), Munich-Zúrich, Piper, 1993, p. 233, carta 135 del 07/09/52. al que este dio lugar. La experiencia vital de Rahel, escritora judía y alemana, es el hilo conductor que le permite a la autora reconocer en la emancipación a la vez una gran promesa y su frustración. Apoyándose en un horizonte de ideas ilustrado, la emancipación, por una parte, prometió a los judíos su integración al mundo político y social, al declararlos, en tanto seres racionales, en pie de igualdad respecto del resto de los ciudadanos. Pero, por otra parte, la noción de razón sobre la que se asentaba este proyecto, postulaba un sujeto abstracto y a-histórico. Según se nos muestra a través de la vida de Rahel, esto implicó para los judíos, que sólo podrían acceder a la esfera de la cultura racional como iguales, renunciando al judaísmo en tanto trasfondo histórico-cultural de identidad y proveniencia. Así, para lograr la asimilación prometida los judíos debían asumir una experiencia de sí indiferente a las singularidades históricas y culturales de su pueblo, ser capaces de sobreponerse a ellas e incluso negarlas. Pero la lección que, a los ojos de Arendt, Rahel comprenderá hacia el final de su vida es, que en ningún caso es posible aparecer, en el sentido arendtiano que luego adquirirá esa palabra, despojada de profundidad histórica, esto es, de la concretud distintiva en que nos es dada la posibilidad de actuar. Sea mostrándose primero como "judía de excepción” en los salones, sea a través del borramiento de las huellas de su judaísmo después, en ambos casos Rahel intentaba un despojo de la propia historia que disuelve las posibilidades de conformar lo que Arendt más tarde llamará un "quién" , y que empuja a los individuos a una negación de sí y de todo lazo posible de comunidad.

En Rahel Varhagen Arendt no se aboca a la reconstrucción sistemática de las concepciones filosóficas de la razón que hicieron posible la emancipación y la asimilación judías. El libro se concentra en la manera en que ambos procesos, con sus paradojas, tomaron cuerpo en la experiencia de una mujer judía. Sin embargo, las referencias a filósofos e ideas que la autora identifica con la Ilustración y el romanticismo son abundantes, y sugieren que ambas corrientes crearon la atmósfera que hizo posible dicha experiencia, en tanto constituyeron los marcos filosóficos que proveyeron de sentidos, tanto a la emancipación y la asimilación, como a su promesa frustrada ${ }^{7}$.

Con todo, Rahel Varnhagen no permite determinar claramente el grado en que, con su análisis de la experiencia judía deshistorizada, Arendt ataca centralmente a los problemas de la razón ilustrada, o la apropiación

Sobre la noción de aparición y el "quién" en sentido político, cf. H. Arendt, La condición humana, trad. R. Gil Novales, Buenos Aires, Paidós, 2009, cap. V.

Es importante distinguir entre la arquitectura filosófica que permitió legitimar la emancipación y la asimilación como proyectos sociales y políticos, y las relaciones de poder que hicieron posible el "Edicto de Emancipación" prusiano de 1812. Para Arendt, la emancipación como hecho jurídico, no es consecuencia de las ideas románticas e ilustradas, sino que, como queda más claro en "Antisemitismo" (en H. Arendt, Escritos Judios, op. cit., pp. 122-195), surge gracias a una singular correlación de fuerzas entre la monarquía, los junkers y la burguesía. A los fines de nuestra investigación dejamos a un lado este segundo nivel de análisis y nos concentramos en su trasfondo filosófico, para desentrañar los efectos que este, según Arendt, supuso para el vínculo de los judíos con la historia. 
romántica de ciertas ideas ilustradas, o a ambas. Por una parte, las premisas básicas del proceso de emancipación son ilustradas, principalmente, la idea de igualdad universal de todos los hombres, en base a su posesión de una razón, concebida en términos abstractos y universales. Esto ha inclinado a algunos intérpretes, a señalar que ya en Rahel Varnhagen, Arendt comienza a desarrollar una crítica profunda a la Ilustración, que cristaliza en el capítulo IX de Los orígenes del totalitarismo ${ }^{8}$. Pero, por otra parte, cuando la autora describe la subjetividad a las que estas premisas dan lugar en la judería de la época, se adentra en terreno romántico. En efecto, la autora asocia al romanticismo un conjunto de elementos que configuran la experiencia del judío que, entregado al proyecto de asimilación, terminar por extrañarse de su historia: una subjetividad centrada en la reflexividad y la introspección, el retiro de lo público en favor de un cultivo de la "intimidad", la idea de hacer de la propia vida una obra de arte, una particular idea de "destino", y la figura del genio9.

Así, aunque Rahel Varnhagen, en efecto, evidencia la mirada crítica arendtiana en relación a las vertientes filosóficas que atraviesan la experiencia de Rahel, quizás debido a su carácter ensayístico y biográfico, el libro deja algunas preguntas importantes sin esclarecer del todo: ¿qué del fracaso de la emancipación y su fallida concepción de razón, asocia Arendt a la tradición ilustrada y qué a los autores vinculados al romanticismo?,

Entre los intérpretes más importantes de Arendt que sostienen esta perspectiva se encuentra R. Bernstein, Hannah Arendt and the Jewish Question, Cambridge, Mit Press, 1996. Podemos mencionar también las interpretaciones de R. Mate, Memoria de Occidente. Actualidad de pensadores judios olvidados, Barcelona, Antrophos, 1997; R. Forster, "El último movimiento mesiánico", en D. Tatián y R. Forster, Mesianismo, nihilismo y redención: de Abraham a Spinoza, de Marx a Benjamin, Buenos Aires, Altamira, 2005, pp. 424-25, sobre las que volveremos hacia el final de nuestra exposición.

9 Para un análisis de algunos de estos elementos románticos en Rahel Varnhagen cf.: L. Keedus, "«The flight into the self»: Arendt on romanticism", en The Crisis of German Historicism: The Early Political Thought of Hannah Arendt und Leo Strauss, Cambridge, Cambridge University Press, 2015, pp. 53-62; S. Benhabib, "The Pariah and her Shadow: Hannah Arendt's Biography of Rahel Varnhagen" en The reluctant modernism of Hannah Arendt, Lanham - Boulder - Nueva York, Rowman \& Littlefield Publishers, 2003, pp. 1-34; y P. Hunziker, "Rahel Varnhagen y las tentaciones del intelectual romántico", en Filosofía, politica y platonismo. Una investigación sobre la lectura arendtiana de Kant, Buenos Aires, Prometeo, 2018, pp. 3539. Como muestran estas contribuciones, la crítica que realiza Arendt en esta época al romanticismo, es más amplia y compleja de lo que se propone reconstruir el presente artículo. Un estudio más completo de este tópico, incluiría un análisis de Rahel Varnhagen, una consideración de la crítica arendtiana a la noción de genio y su influencia en la cultura alemana en distintos escritos, y una reconstrucción del vínculo entre estas perspectivas y las desarrolladas por algunos referentes de la época, como ser el Carl Schmitt de Romanticismo Politico (Buenos Aires, Universidad Nacional de Quilmes, 2005), los estudios benjaminianos sobre romanticismo (El concepto de crítica del arte en el romanticismo alemán, Madrid, Península, 1988) y los volúmenes de Friedrich Gundolf -a cuyas clases, tanto Arendt como Benjamin asistieron- dedicados a esta corriente (Romantiker, Berlín-Wilmersdorf, Keller, 1930; Romantiker. Neue Folge, BerlínWilmersdorf, Keller, 1931). En esta última dirección avanzan: L. Keedus. "«The flight into the self»: Arendt on romanticism", op. cit. (con un análisis de la importancia de Gundolf para el pensamiento de Aendt); y M., Löwy, "Hannah Arendt y Walter Benjamin", en Judios Heterodoxos. Romanticismo, mesianismo, utopía, Barcelona, Anthropos, 2015, pp. 59-70. ¿entiende Arendt, que, en lo que concierne a la experiencia judía, ambas tradiciones se encuentran en continuidad?, ¿qué legados recupera de estas tradiciones, no obstante ello? Finalmente: ¿cómo se vincula este análisis filosófico con el diagnóstico del presente que es su punto de partida, esto es, la impotencia de los judíos frente al ascenso del antisemitismo en Alemania?

"La Ilustración y la cuestión judía", un escrito breve y considerado menor de esta misma época, puede contribuir a esclarecer estos interrogantes. Fechado en 1932, el ensayo desarrolla de manera más extendida y conceptualmente sistemática algunos pasajes contenidos en el capítulo segundo de Rahel Varnhagen. El escrito se centra en las raíces teóricas de la amalgama entre asimilación y falta de sentido histórico. Su hilo conductor es el papel que jugó en los proyectos de asimilación y defensa de la igualdad de los judíos del siglo XVIII alemán, la distinción entre verdades históricas y verdades de razón. La reconstrucción de esta distinción recorre los escritos de un conjunto de pensadores, y permite comprender con mayor profundidad la posición crítica que Rahel Varnhagen expresa en términos menos sistemáticos y más generales.

Si las verdades de razón aluden a un conjunto de principios universales que todos pueden compartir a través del razonamiento, las verdades históricas refieren, en cambio, a aquellas verdades a las que los seres humanos pretenden haber accedido mediante la experiencia histórica, en particular, a los artículos de fe de las distintas religiones que fueron revelados en momentos determinados a través de las escrituras. Se trata de verdades vinculadas a las historias singulares de los pueblos. Dado que en principio los dos tipos de verdades pueden colisionar, una pregunta fundamental para garantizar la integración del judaísmo, concebido como religión particular, a la cultura ilustrada universalista, consiste, según la autora, en cómo comprender y resolver las tensiones que se desprenden de este vínculo: entre lo que la razón enseña con el razonamiento, y lo que la tradición religiosa ha enseñado históricamente a través de sus profetas e hitos.

Aunque "La Ilustración y la cuestión judía" no se detenga en ello, Arendt es consciente de que la concepción del judaísmo como una religión, y el planteo del problema de cómo garantizar su integración, como un problema de tolerancia religiosa, es parte ya de la perspectiva asimilacionista y resulta problemática ${ }^{10}$. De todas maneras, para Arendt, el modo en que los filósofos conciben y problematizan las verdades históricas, como verdades vinculadas a la religión, resulta relevante para dar cuenta de su concepción de la historia en general. Como veremos, el foco del ensayo, está puesto en realidad en este punto. El texto recorre las distintas respuestas a la pregunta por la relación entre verdades históricas y verdades de razón, a lo largo de un arco que se tensa entre Lessing y Herder. A continuación, nos detenemos en los momentos clave de este recorrido.

Lessing constituye el punto de partida de "La Ilustración y la Cuestión Judía" porque es, para Arendt, el

\footnotetext{
0 Sobre la opinión de Arendt sobre la reducción del judaísmo a una religión, cf. H. Arendt, "Antisemitismo", en Escritos Judios, op. cit., pp. $122-195$
} 
autor que más se acercó a formular una articulación no dicotómica entre razón e historia. La autora se centra en los escritos en los que el filósofo se traba en polémicas teológicas con sus contemporáneos durante la década de 1770, y encuentra allí una idea de humanidad anclada a una noción de "razón común" que se despliega como búsqueda nunca acabada de lo verdadero [das Echte $]^{11}$. Lo importante de esta identificación entre razón y búsqueda es que desestima la importancia de la posesión efectiva de una verdad última, que, en términos teológicos, ya no es "garantía objetiva de salvación". Esto permite a Lessing proponer como principio político-filosófico una noción de tolerancia que no se identifica con la aceptación de lo equivocado en nombre de la piedad, sino que debe entenderse como la afirmación de las diferencias religiosas en nombre de una común humanidad que todas ellas expresan, en tanto formas históricas específicas de esta búsqueda. A los ojos de Arendt, lo central de esta noción de verdad es que no nos aparta del mundo de los asuntos humanos, sino que nos reconduce a lo humano en cuanto tal, para afirmar su "carácter eternamente inacabado y fragmentario". Más aún, si bien se trata de una "razón formal", ella no es afirmada por sí misma, sino que interesa en tanto que es una "herramienta para el descubrimiento de lo humano"

Desde este punto de vista, Lessing propone una consideración de doble cara sobre la autonomía de la razón respecto de la historia. Frente a la pregunta central ¿puede alguna tradición religiosa reclamar autoridad por sobre la razón?, Lessing responde negativamente al afirmar que "la historia revelada" queda subordinada a la razón, aun cuando deba ser tolerada en cuanto legítima expresión de una forma histórica de la búsqueda de la verdad. Así, sin renunciar a los contenidos de la fe, Lessing afirma que no es la historia preservada en las escrituras sagradas la que provee de verdades a los seres humanos, sino la razón humana la que puede confirmar el sentido de lo legado como historia revelada. Las "verdades de razón" (que no debemos entender aquí como verdades últimas, que harían cesar el movimiento de búsqueda, sino como el fruto provisorio del movimiento infinito de la razón) son el juez de aquello que la historia revelada parece presentar como verdadero ${ }^{13}$.

Sin embargo, destaca Arendt, aunque la historia quede subordinada de este modo a la razón, es el medio a través del cual la razón se despliega. Por tanto, tiene una función pedagógica. La historia revelada, que interpela a la razón y pide su confirmación, es "la encargada de la educación (Erziehung) del género humano"14. Es gracias

11 Las referencias son aquí: G. E. Lessing, "Eine Duplik”, “AntiGoeze", "Über den Beweis des Geistes und der Kraft", en K. Lachmann (ed.), Sämmtliche Schriften. Neue rechtmäßige Ausgabe, vol. X, Berlin, Voß'schen Buchhandlung, 1839; Fragmente eines Ungennanten, Hamburgo, Gernot Fligge, s/f.

12 H. Arendt, "La Ilustración y la cuestión judía", op. cit., p. 83.

13 Cf. ibidem, p. 80. Arendt se remite aquí especialmente a "Ein Mehreres aus den Papieren des Ungenannten, die Offenbarung betreffend", en Fragmente eines Ungennanten, op. cit.

14 H. Arendt, "La Ilustración y la cuestión judía", op.cit., pp. 80-81. Notemos que Arendt no utiliza aquí el término Bildung, cuyas connotaciones, están para ella mayormente vinculadas a la tradición romántica, aunque no considere que exista un sentido unívoco de este término. En efecto, Arendt reconocerá que la Bildung adopta a un proceso histórico-educativo previo a la Ilustración -en donde la historia revelada tiene un papel central-, que las personas llegan a "la mayoría de edad", punto a partir del cual gozan de la razón en un sentido pleno. Pero una vez alcanzada esta mayoría de edad, continúa Arendt, la razón se desplegará asimismo en la historia en un camino infinito de eterna búsqueda. Dado que la razón es búsqueda inacabable y no posesión de la verdad, la mayoría de edad no es el fin de la historia, sino un recomienzo; el momento en que el que los seres humanos fundan una nueva historia. Por ello,

esta historia que hay que fundar está completamente anclada en el pasado. Es el pasado dominado por la autoridad que es el educador. La mayoría de edad del hombre es el resultado de un proceso, el producto de una educación [Erziehung] que Dios concedió a los hombres ${ }^{15}$.

Así Lessing, según Arendt, afirma una noción relativa de la autonomía de la razón frente a la historia, que supone a la vez superioridad (porque la razón tiene la última palabra sobre la historia) y dependencia (porque la razón se despliega históricamente como búsqueda). Para los judíos, esta concepción tensionada, significa, por un lado, que su historia religiosa particular no puede colisionar con las verdades de la razón ilustrada y, por tanto, que su interpretación queda subsumida a las orientaciones que proveen las verdades de razón. Pero, al mismo tiempo, la historia religiosa no debe ser desechada sin más, porque expresa una búsqueda legítima de la verdad. Aunque valora en Lessing este esfuerzo por entrelazar de manera no dicotómica historia y razón, Arendt reconoce también que se inaugura así un camino de tensiones entre ambos términos; camino que pronto toma un rumbo problemático. En La educación del género humano ${ }^{16}$, de 1780 , la autora juzga que esta perspectiva sobre la historia es abandonada, como así también es eludida la idea de una verdad de carácter "inacabado y fragmentario".

"La Ilustración y la Cuestión Judía" continúa señalando que esta distinción entre razón e historia será revisitada en las siguientes generaciones de ilustrados quienes, al igual que Lessing, abogarán por la igualdad e integración de los judíos, aunque desde distintas perspectivas. Un contemporáneo clave es Mendelssohn. Este filósofo judío recupera la distinción de Lessing entre verdades históricas y verdades de razón, pero abre entre ambas un abismo que se volverá imposible de franquear. A la base de este movimiento se encuentra la singular interpretación mendessohniana del "pensar por sí mismo" (Selbstdenken) ilustrado:

Esta capacidad de pensar por sí mismo [el Selbstdenkenkönnen que "ha revindicado para el hombre la Ilustración"]

distintos sentidos en autores como Goethe, Humboldt, Mendelssohn o Herder. Sobre su interpretación de las concepciones de estos dos últimos, nos referiremos brevemente a continuación.

Ibidem, p. 82.

16 G. E. Lessing, La educación del género humano, Barcelona, Azul, 2008. Original en G. E. Lessing, "Die Erziehung des Menschengeschlechtes", Sämmtliche Schriften. Neue rechtmäßige Ausgabe, op. cit. 
constituye la base del ideal de formación [Bildung] de Mendelssohn: la auténtica formación [Bildung] no se nutre de la historia [Geschichte] y de sus hechos, sino que vuelve a ésta superflua. La única autoridad es la de la razón, a la que todo hombre es capaz de acceder en solitario y por sí mismo. El hombre que piensa vive en un asilamiento absoluto: separado del resto, encuentra la verdad, que propiamente debería ser común a todos [...]. En Mendelssohn, la razón se vuelve todavía más independiente de la historia, ya no tiene ningún punto de anclaje en ella [...] El conocimiento de la historia no es siquiera necesario para la formación [Bildung] de Mendelssohn: ésta no es más que la libertad de pensamiento ${ }^{17}$.

De este modo, Mendelssohn reduce el concepto ilustrado de "autonomía de la razón" (autonome Vernunft) a la capacidad de pensar por sí mismo (Selbstdenkenkönnen), y define a esta por su independencia del mundo común compartido que constituye la historia ${ }^{18}$. Afortunadamente, en la religión judía existen para Mendelssohn verdades eternas que pueden ser captadas por la razón $\mathrm{y}$ en las que los judíos coinciden racionalmente con los demás pueblos.

Sin embargo, esto no implica que sólo pueda preservarse de la religión judía esos contenidos racionales y universalmente compartibles, es decir, sólo aquellos contenidos que pueden comprenderse con independencia de la historia judía particular. Mendelssohn afirma además la existencia de leyes religiosas (esto es, prescripciones y no verdades), históricamente reveladas, que están más allá de la razón, y que sin embargo resultan obligatorias para el pueblo que las ha recibido. En términos prácticos, reconstruye Arendt, esto supuso para los judíos, a la vez, el deber de preservar el ejercicio de su religión en su singularidad, a través de la observancia de las leyes reveladas, y el deber de adaptarse a un mundo en el cual la tolerancia debía expandirse en base a las "verdades eternas" que su religión compartía con el cristianismo y que eran asequibles para todos.

De cualquier modo, al sustraer a las leyes que han sido reveladas históricamente de su contenido racionalverdadero, a los ojos de Arendt, Mendelssohn termina por radicalizar la separación entre búsqueda de la verdad o razón, e historia. Sino es posible aspirar a que la historia reciba confirmación o legitimación de sus verdades a través de la razón, se desvanece completamente su carácter pedagógico. El punto central es que, para el filósofo, la historia debe ser preservada religiosamente, pero no es relevante para la inclusión de los judíos en el mundo secular, donde ellos sólo cuentan como seres racionales, sin historia.

17 H. Arendt, "La Ilustración y la cuestión judía", op.cit., p. 83. El contraste con el alemán indicado en corchetes se realizó en base a $\mathrm{H}$. Arendt, "Aufklärung und Judenfrage", Zeitschrift für die Geschichte der Juden in Deutschland 4, 1932, p. 68 (consultado en Hannah Arendt-Archiv, Carl von Ossietzky University Oldenburg). La autora refiere en estos pasajes a M. Mendelssohn, "Jerusalem, oder über Religöse Macht und Judentum” (vol. I, p. 318) y "Briefwechsel mit Bonnet", (vol III, pp. 108-126), en Gesammte Schriften, Leipzip, Brodhaus, 1845.

18 H. Arendt, "La Ilustración y la cuestión judía", op. cit., p. 83.
Por otra parte, Arendt señala que esta, aun cuando está a su base, no es la concepción de la historia que los judíos asimilados finalmente "hicieron suya"19 y que terminó por afirmar "la indiferencia del judío hacia la historia"20. Dos figuras serán centrales para llegar a la legitimación del proyecto asimilacionista más radical en sus pretensiones: Dohm y Friedländer. Estos autores abandonan la intención de legitimar el judaísmo en su singularidad que todavía sostenían Lessing y Mendelssohn. Arendt señala que el proyecto de asimilación de Dohm en Sobre el mejoramiento de la condición civil de los judios ${ }^{21}$, igual que el de Friedländer ${ }^{22}$, implica el total borramiento de las diferencias entre judíos y gentiles y, por tanto, una nueva actitud hacia la historia. Mientras que Mendelssohn se había limitado a desestimar el valor pedagógico-racional de la historia $\mathrm{y}$, por consiguiente, su importancia y sentido para una cultura secular compartida, Dohm y Friedländer, otorgan a la historia un valor totalmente negativo: ella es la que forjó a los judíos en su singularidad, distorsionando su calidad de iguales, por lo que no puede ser considerada sino una fuente de la corrupción. La consecuencia de esto es que, así la historia para los judíos se convierte en:

la historia de los prejuicios en los que estaban atrapados los hombres antes de la época de la Ilustración: la historia es la historia de un pasado malo o de un presente que todavía está bajo el poder de los prejuicios. El objetivo de la integración social y de la liberación de los judíos es precisamente librar al presente de las cargas y de las consecuencias de esta historia ${ }^{23}$.

Esta generación de intelectuales es la que dio lugar a la idea de que el reconocimiento ilustrado de la igualdad de los judíos requería su identificación cultural con la comunidad en la que ingresan como iguales. Arendt es especialmente crítica con ellos, quienes

se identifica[n] hasta tal punto con la ceguera de la Ilustración, para la que los judíos no son más que gente oprimi$\mathrm{da}$, que renuncia[n] a su propia historia y considera[n] que todo lo suyo es tan sólo un obstáculo para su integración real en la sociedad, para su autorrealización como seres humanos ${ }^{24}$.

De este modo se consuma la abstracción que es característica de la manera ilustrada predominante de tratar la cuestión judía. La consideración de los judíos como "pueblo oprimido", pero despojado de toda historicidad particular, afirma al judío como figura abstracta que representa la opresión. Su liberación se convierte así en símbolo abstracto de la universalidad de los derechos

\footnotetext{
Ibidem, p. 85

20 Ibidem, p. 84. En la versión alemana original Unverständnis der Juden für Geschichte, H. Arendt, "Aufklärung und Judenfrage", op. cit., p. 69.

${ }_{21}$ C. W. von Dohm, Über die bürgerliche Verbesserung der Juden, Göttingen, Wallstein, 2015.

22 La autora refiere especialmente el escrito anónimo que D. Friedländer dirige a Wilhelm Abraham Teller Sendschreiben einiger jüdischer Hausväter, Nürenberg, Rawschen Buchhandlung, 1800.

23 H. Arendt, "La Ilustración y la cuestión judía", op. cit., p. 85.
}

24 Idem. 
humanos. Arendt considera que esta abstracción permitió a los defensores de los judíos ignorar a sus defendidos en su particularidad concreta y su condición histórica. Según anota en un manuscrito de la misma época:

No es un accidente que cuando la cuestión judía se plantea de esta manera fundamental los judíos se convierten en poco más que un ejemplo, casi un mero pretexto y que sus amigos los vean como nada más que un principio dentro de un proceso, y que ni siquiera una vez en el triste curso de esta historia durante los últimos ciento cincuenta años hayan sido considerados por los demás como seres humanos de verdad ${ }^{25}$.

Arendt entenderá que esta manera de considerar al judío como principio abstracto adelanta la consideración del antisemitismo moderno del judío como principio abstracto que representa el mal. El antisemitismo moderno se caracteriza por "transformar al judío como individuo de carne y hueso en un principio, en un conglomerado de característica que son universalmente malas"26. Lo que tiene en común esta concepción con la Ilustración es su abstracción. Mientras que para la Ilustración el judío es el principio abstracto de la humanidad, para los antisemitas es el principio abstracto del mal. En este sentido afirma la autora: "La forma clásica en la que la Ilustración planteó la cuestión judía suministra al antisemitismo su base teórica" ${ }^{27}$. Sin embargo, debemos avanzar en el análisis para precisar el alcance y sentido de esta provocativa tesis que anuda fuertemente Ilustración y antisemitismo.

"La Ilustración y la cuestión judía" termina su recorrido con una figura que juega un rol clave en la interpretación arendtiana de la emancipación judía: J. G. Herder. De la reseña del libro de Hans Weil La aparición del principio alemán de Bildung ${ }^{28}$, se desprende que, para Arendt, Herder ocupa un lugar central en la atmósfera ilustrada de la época de Rahel, por dos razones importantes para nuestra reconstrucción. Por una parte, Arendt reconoce con Weil la influencia de Herder en los ideales de "formación" (Bildung) de lo que el autor llama la

${ }_{25}$ H. Arendt, "Antisemitismo", op. cit., p. 142. Traducción española corregida ligeramente en su cotejo con la versión inglesa: H. Arendt, "Antisemitism", en H. Arendt The Jewish Writings, op. cit., p. 134. Esto permite comprender la paradoja de que W. von Humboldt, siendo defensor de la emancipación, según cita Arendt, afirmase: "Realmente sólo quiero al judío en masse; en détail lo evito sistemáticamente" (H. Arendt, "Las enseñanzas de la historia", en Escritos Judios, op. cit., p. 404). Arendt cita aquí a Humboldt en Anna von Sydow (ed.), Wilhelm von Humboldt und Karoline von Humboldt in ihren Briefen, Berlín, 1900, vol. V, p. 236. En una línea similar, Arendt escribirá en su Diario Filosófico: “el camino erróneo: amar en un hombre lo universal, convertirlo en un recipiente $[\ldots]$ lo cierto es que se da en ello casi un asesinato potencial, una especie de sacrificio humano" (H. Arendt, Diario filosófico, 1950-1973, U. Ludz e I. Nordmann [eds.], trad. R. Gabás, Barcelona, Herder, 2006, p. 15).

26 H. Arendt, "Antisemitismo", op. cit. pp. 142-43.

Ibidem, p. 142. Bastardillas en el original.

28 H. Arendt, "La aparición del principio alemán de Bildung de Hans Weil", en H. Arendt, Más allá de la filosofia: escritos sobre cultura, arte y literatura, Madrid, Editorial Trotta, 2014, pp. 198-205. El texto es una reseña de H. Weil, Die Entstehung des deutschen Bildungsprinzip, Schriften zur Philosophie und Soziologie, Bonn, Friedrich Cohen, 1930. "elite intelectual" de la época ${ }^{29}$, ideales a partir de los cuales nacen las tensiones que se exponen en Rahel Varnhagen. Por otra parte, Herder es la primera expresión de lo que Arendt considera la verdadera oposición a la elite intelectual ilustrada: la "tradición histórica". La reivindicación romántica de lo histórico a la que Herder da lugar con su concepto de Bildung, se opone precisamente a la individualidad desencarnada, abstracta, de la elite intelectual ilustrada.

Con la publicación de Otra filosofía de la historia para la educación de la humanidad" ${ }^{30}$. Herder "arremete contra la omnipotencia de la razón"31 que empezó a delinearse a partir de Mendelssohn y propone un retorno a la historia. Pero es importante notar que Arendt no presenta la oposición Ilustración vs. romanticismo herderiano en términos estancos. Por el contrario, interpreta este giro crítico de Herder frente a la Ilustración como un intento por "prolonga[r] el descubrimiento de la historia iniciado por Lessing" 32 . Podríamos decir que, desde la perspectiva de Arendt, Herder encuentra dos caminos frente a la dicotomía historia-razón, tal como la planteó Lessing. Por un lado, es posible acentuar la razón, como hicieron Mendelssohn, Dohm y Freidländer. Pero el resultado es la abstracción y sus perplejidades. Por tanto, concluye Herder, queda el camino inverso: recuperar el valor de la historia. Así, el filósofo romántico retoma la importancia que Lessing le otorga a la historia como medio de formación, pero intenta profundizarla.

Arendt recupera de Ideas para una Filosofía de la Historia de la Humanidad ${ }^{33}$, de Herder, la observación de que la importancia de la historia en Lessing en realidad es limitada y está obturada por la primacía que el ilustrado otorga a la razón. Pues si bien Lessing había afirmado que la historia es fundamental para la educación (Erziehung) del género humano, en la medida en que la concibe subordinada a la razón, en realidad supone que ella "no añade al hombre nada distinto de lo que éste ya es por naturaleza" 34 . La historia así entendida no tiene ningún valor añadido a la razón; sólo testimonia a su favor. Entonces, es la propia concepción ilustrada de educación centrada en el Selbstdenken lo que debe ser cuestionado. En palabras de Arendt, Herder le reprocha al concepto ilustrado de Selbstdenken su "absoluta falta de realidad", porque se desentiende de la experiencia y es "incapaz de conservar el pasado" "35. Para Herder, en cambio, la verdadera educación, se da a través del pasado, se nutre de la historia. En este marco el filósofo

29 Esto lo señala Hans Weil en su libro, y Arendt no lo discute y lo asume en su reseña.

30 J. G. Herder, Ensayo sobre el origen del lenguaje. Otra filosofía de la historia para la educación de la humanidad. Ideas para la filosofia e la historia de la humanidad (selec.). Una metacrítica de la Crítica de la razón pura, Madrid, Gredos, 2015.

31 H. Arendt, "La Ilustración y la cuestión judía”, op. cit., p. 87.

32 Idem. Significativamente, una de las críticas que Arendt dirige a Hans Weil apunta a su subestimación de la influencia de Lessing sobre el concepto de formación de Herder, Cf. H. Arendt, "La aparición del principio alemán de Bildung de Hans Weil”, op. cit. p. 200.

33 J. G. Herder, Ideas para una Filosofia de la Historia de la Humanidad, trad. J. Rovira Armengol, Buenos Aires, Losada, 1959.

34 H. Arendt, "La Ilustración y la cuestión judía", op. cit., p. 87.

35 Ibidem, p. 90. 
redefine los conceptos de razón, historia y educación, comprendida como formación, Bildung ${ }^{36}$.

Para Herder, señala Arendt, la razón ya no es la jueza última de la historia, sino sólo uno de sus resultados, posible, pero no necesario. La razón tampoco permite desentrañar la historia; no es posible con su ayuda determinar cuál es su fin último o el sentido de su desarro1lo. La historia se vuelve opaca para la razón ${ }^{37}$. Por otro lado, la historia es aquello que constituye la singularidad de los individuos y los pueblos, es lo que hace que éstos sean lo que son. Desde el punto de vista político, el valor de la historia no se encuentra en que conduce o confirma la universalidad racional, sino en que es lo que hace a los pueblos diferentes unos de otros como integrantes de la humanidad. Los seres humanos no se caracterizan por su igualdad garantizada por la posesión de una misma razón, sino por su diferenciación a partir de devenires históricos diversos.

Ahora bien, esto no significa que no exista un concepto de humanidad y que Herder afirme la pluralidad de meros particularismos incapaces de salir de sí mismos. Los pueblos logran formar parte de la común humanidad a través de la "formación" (Bildung), la cual, en la lectura arendtiana de Otra filosofía de la historia para la educación de la humanidad, consiste en una comprensión distanciada de la historia. Es decir, a través del distanciamiento comprensivo en relación a los pasados, cada pueblo puede captar cómo ha contribuido con su pasado particular a una misma "cultura del género humano", una cultura cuya posesión común y comprensión excede a cada particularidad y define la común humanidad.

Es aquí precisamente donde Arendt ve el principal problema de la consideración herderiana de la cuestión judía. Herder también apoya la igualdad de los judíos. La autora rescata incluso que es el primero que plantea el asunto en términos políticos, en el sentido de que la convierte en una cuestión de Estado y supone que implica la integración de un pueblo al Estado a través de un conjunto de derechos. Por tanto, no entiende al judaísmo sólo como una religión y la cuestión judía como un problema de convivencia entre religiones distintas. El judaísmo es, más bien, "una aspiración nacional". Pero el problema está en que, desde su perspectiva, la asimilación judía pasa a depender de un proceso de formación (Bildung) que distancia a los judíos de su historia.

La noción herderiana de comprensión supone una toma de distancia tal frente a su objeto que implica, para quien comprende, la disolución no sólo de todo carácter normativo, sino incluso vinculante en algún sentido. En palabras de Arendt, la comprensión para Herder consiste en:

mantener una distancia en relación con el pasado: evitar confundirse con él, tomar completamente en serio el espacio de tiempo que media entre él y el sujeto de la comprensión, incorporar esa distancia en el acto de comprensión.

\footnotetext{
36 En Herder la autora alude a una "educación a través de la formación": Erziehung durch Bildung, ibidem, p. 75.

37 Arendt analiza esta idea en J. G. Herder, "Erläuterung zum Neuen Testament", en Sämmtliche Werke, Stuttgart-Tübingen, Gotta'schen Buchhandlung, 1829, vol. XI, libro 2, apartado III.
}

De este modo [...] la historia no es vinculante para quien la comprende $[\ldots]$ su función formativa radica en la comprensión como tal ${ }^{38}$.

A partir de esto, la autora concluye que, a pesar de la afirmación romántica de la historia frente a la razón, el resultado no es una devolución a los judíos de su propia historia, sino una mayor desvinculación. En la Ilustración incluso todavía se conservaba, aunque de forma tenue o subordinada, un vínculo significativo con un pasado particular, que, dice Arendt "ahora desaparece totalmente" "39. El modelo herderiano de asimilación es el judío culto que ha abandonado toda identificación con el pasado judío y considera la historia de su pueblo sólo desde la perspectiva de su contribución a una "cultura del género humano" que la trasciende. En la medida en que debe a travesar un proceso de formación, no es cualquier judío sino un judío de excepción, porque es aquel que puede demostrar con su carácter cultivado (gebildet) su asimilación ${ }^{40}$. En este aspecto, su carácter cultivado, el judío asimilado de Herder se parece a Mendelssohn, pues es un judío que porta y muestra una diferencia respecto de su identidad tradicional: la identificación con la gran cultura en la cual se condensan los logros históricos de los pueblos, y a la luz de la cual se confirma su credencial de pertenencia a la humanidad. Así, la cultura entendida de este modo es para los judíos, según Arendt, una invitación a la negación de sí. Pues en la medida en que la cultura es una esfera en relación a la cual los judíos sólo han contribuido con una pequeña parte, el ingreso en ella implica siempre que "el judío culto necesita constantemente de un pasado que le es ajeno"41. En relación a Herder, Arendt entonces concluye:

La plena igualdad de Lessing sólo exigía de los judíos humanidad, algo que finalmente, sobre todo en la interpretación de Mendelssohn, también podían lograr. Aquí en cambio, se les pide que sean especiales, y en tanto que tales se les incluye indiferenciadamente en la "cultura del género humano", después de que la "formación", la distancia característica del acto de comprensión, haya destruido todos los contenidos en los que los judíos podían basar su especificidad [...] Así los judíos se convierten en los sin historia de la historia. La comprensión herderiana de la historia les ha arrebatado su pasado. Vuelven a estar vis a vis de rien ${ }^{42}$.

Arendt finaliza su análisis con una alusión a Leopoldo Zunz, uno de los fundadores de la Ciencia del Judaísmo (Wissenschaft des Judentums). Esta escuela, fundada en 1819, fue el pulmón intelectual de la Asociación Central de Ciudadanos Alemanes de Fe Mosaica (Zentralverein

\footnotetext{
H. Arendt, "La Ilustración y la cuestión judía”, op. cit., pp. 90-91. Ibidem, p. 92.

40 Arendt ejemplifica esta idea con pasajes de "Adrastea" (vol. X), en Sämmtliche Werke, op. cit. La figura del "judío de excepción”, ocupará a Arendt en distintas ocasiones. Cf. "Antisemitismo", op. cit., y "Privileged Jews", Jewish Social Studies 1, vol. 8, 01/1946, pp. 3-30, textos luego incorporados con modificaciones a la primera parte de Los origenes del totalitarismo, op. cit.

41 H. Arendt, "La Ilustración y la cuestión judía", op. cit., p. 93.

42 H. Arendt, "La aparición del principio alemán de Bildung de Hans Weil”, op. cit., p. 93.
} 
deutscher Staatsbürger jüdischen Glaubens), institución contemporánea a Arendt, y promotora del tipo de asimilación cultural judía que ella especialmente criticaba ${ }^{43}$. $\mathrm{La}$ autora sugiere que lo que prevalece en la corriente que representa Zunz es el típico abordaje "distanciado" de la historia, en donde lo que queda en primer plano es su "carácter ajeno" "44. Encontramos aquí una vinculación entre Reforma judía y decepción romántica frente a la razón. Según esta sugerencia, la impotencia del abordaje de la historia típico de la Ciencia del Judaísmo (su distanciamiento, su pretendida neutralidad, su disolución de los contenidos históricos que puedan tener valor de verdad o ser orientadores para la acción), tiene su raíz en la impotencia que el romanticismo de Herder atribuye a la razón frente a la historia ${ }^{45}$.

De este modo, si bien Herder ha repuesto la cuestión de la historia, esta historia está vacía de contenido significativo, no sólo en términos religiosos -como importa en la discusión en el siglo XVIII-, sino que también en términos políticos, lo cual es la principal preocupación de Arendt. La historia, de esta manera, a la vez que pierde su carácter prescriptivo para la práctica religiosa, se convierte, para la vida política de los pueblos, "en algo sobrehumano, impersonal" ${ }^{\prime 4}$. No es el horizonte de lo producido por hombres y mujeres como actores, sino un despliegue de logros en cuya consecución los individuos no son partícipes significativos. Es llegado a este punto que se perfila con mayor claridad el sentido de la mirada crítica de la autora en relación al gran escritor romántico. Finalmente, la preponderancia de la historia, termina por hundir, como las demás filosofías de la historia de

Sobre el papel de esta institución y de la Ciencia del Judaísmo en relación a la asimilación judía en Alemania cf. E. Traverso, El final de la modernidad judia, op. cit., p. 53. El abuelo paterno de Arendt, Max Arendt, perteneció a esta institución, lo cual es un indicio del grado en que esta crítica de Arendt es también una confrontación de sus propios orígenes, como perteneciente a una familia judía asimilada. Según señala Young-Bruhel, la familia materna de Max Arendt, había inmigrado a Königsberg desde Rusia en la época de Mendelssohn, y fue atraída por las ideas de este ilustrado. Cf. Young-Bruehl, Hannah Arendt: una biografia, Barcelona, Paidós, 2006, p. 68.

44 H. Arendt, "La Ilustración y la cuestión judía [1932]", op. cit., p. 93.

45 Esta asociación entre romanticismo y Reforma judía se encuentra también en H. Arendt, "Una revisión de la historia judía", Escritos judios, p. 395. Allí, Arendt considera que la Reforma Judía no puede comprenderse como una mera traducción judía del espíritu ilustrado, esto es, como el resultado de "una asimilación mecánica de las ideas y exigencias de un entorno ajeno", ibidem, p. 395. Por el contrario, retomando a G. Scholem en Major Trends in Jewish Mysticism, Nueva York, Schocken Books, 1961, considera que cabe mejor interpretarla como "la culminación del desastre" sabbaitaino. Tal culminación consiste en una respuesta de fondo nihilista frente a la pérdida de la esperanza mesiánica. Esto le permite a la autora trazar un paralelismo no entre reformismo e Ilustración, sino entre reformismo y romanticismo. En relación al fracaso del movimiento místico de Sabbatai Zevi señala: "Un derrumbamiento similar de las normas religiosas, seguido de un grado similar de desesperanza, constituyó también una de las experiencias destacadas de Europa después de la Revolución francesa. Pero, así como el pesimismo romántico desesperaba de la capacidad política del hombre como legislador y se resignaba a considerarlo capaz sólo de obedecer leyes, cuya legitimación última no residía ya en Dios, sino en la historia y la tradición, el nihilismo judío se alimentaba de la falta de esperanza en la capacidad del hombre para llegar a descubrir las leyes ocultas de Dios y actuar de conformidad con ellas" (idem).

46 H. Arendt, "La Ilustración y la cuestión judía", op. cit., p. 88. esta época, la autonomía de los hombres frente a fuerzas impersonales:

A través de la irrupción de la historia, y por consiguiente de una realidad sobre la cual el ser humano no tiene ningún poder, en la obra de Herder se lleva a cabo una destrucción de la autonomía humana: el ser humano es solo la "hormiga $[\ldots]$ sobre la gran rueda del destino" ${ }^{\prime 4}$.

\section{Ilustración y romanticismo frente a la historia: un balance}

Algunos intérpretes destacan la valoración positiva de Herder frente a la Ilustración que desarrollaría Arendt en este período ${ }^{48}$. Pero de acuerdo a nuestra reconstrucción, la crítica arendtiana a la Ilustración no da como resultado una valoración de su oponente que, en los aspectos que interesan aquí, está representada por la filosofía romántica de Herder. Entendemos que Arendt no asume la negación de la autonomía humana en la filosofía de la historia herderiana como el fruto de una mala interpretación, sino como una consecuencia de sus premisas. En este sentido, la autora no cambia de opinión cuando, en sus escritos maduros, acusa a la filosofía de Herder de ser pareja a la filosofía de la historia hegeliana y, por tanto, de sustraer a los seres humanos su capacidad de comprensión, juicio y autonomía en relación a la historia.

Esto podría dar lugar a otro camino de interpretación: si la perspectiva crítica de Arendt no realiza una contraposición entre Ilustración y romanticismo, se dirige entonces en señalar una continuidad. Entre Ilustración y romanticismo existiría una continuidad de modo que incluso podría pensarse que la filosofía de la historia de Herder y su consideración de la cuestión judía es la consecuencia o la profundización lógica de ciertas ideas propuestas por la generación ilustrada a la que perteneció Lessing. ¿Es esta la postura de Arendt, o existen para ella saltos teórico-políticos significativos entre ambas perspectivas?

En principio, podemos decir que, a partir de ciertos movimientos teóricos, Arendt sugiere que el romanticismo herderiano extrema una pérdida que para ella ya está contenida en la idea ilustrada y lessingiana de razón. Podríamos señalar que, desde su perspectiva, la

\footnotetext{
7 H. Arendt, "La aparición del principio alemán de Bildung de Hans Weil", op. cit., p. 201. Arendt cita a Herder sin referencias bibliográficas.

48 Este es el caso de: E. Young-Bruehl, Hannah Arendt: una biografia, op. cit., pp. 160-61; N. Sznaider, La memoria judia y el orden cosmopolita, Buenos Aires, Capital Intelectual, 2012, pp. 34-35; R. H. King, "On Race and Culture. Hannah Arendt and her contemporaries", en S. Benhabib, Politics in dark times: Encounters with Hannah Arendt, Cambridge, Cambridge University Press, 2010, pp. 125-26; A. Della Bianchina, "Kultur versus Bildung: amicizia e resistenza in Hannah Arendt", Studi sulla Formazione/Open Journal of Education 19, $\mathrm{n}^{\circ} 1,2016$, p. 148. Esta sobrevaloración de la lectura arendtiana de Herder en términos positivos, en algunos casos, posiblemente se vincule a una interpretación sesgada de su crítica a la Ilustración en términos puramente negativos. Se trata de lecturas que dejan caer su acento en el vínculo entre antisemitismo e Ilustración que Arendt sugiere en algunos pasajes que analizamos a continuación. Como veremos, estas sugerencias requieren ser matizadas.
} 
Ilustración, que hizo posible independizar al hombre de la historia como tradición autoritativa y como determinación divina, no encontró los medios suficientes para "humanizar" esa historia. De este modo, la Ilustración facilitó la sustracción de la historia del espacio "entre" los seres humanos, y su desvanecimiento, no sólo como referencia religiosa, sino también como horizonte de lo político. Pues de este modo, obturó una comprensión filosófica de la historia como aquello que los hombres hacen y aquello que constituye el trasfondo partir de lo cual aparecen en cuanto actores. Esta incomprensión está a la base de todas las filosofías de la historia moderna que, como Herder, no pueden sino concebir a la historia como una fuerza supra-humana. En suma, una característica central de la Ilustración, que el romanticismo herderiano no hará sino profundizar, consiste en no poder incorporar al espacio abierto para la libertad, igualdad y dignidad humanas, esto es, a los conceptos de humanidad y razón ilustrados, un lugar adecuado para la historia. Así, aunque guarda simpatía por el concepto de Lessing de humanidad y su aspiración a la igualdad, Arendt critica los cimientos sobre los que este concepto y su aspiración están anclados.

No obstante, es importante señalar que el desarrollo de la distinción entre razón e historia que reconstruye "La Ilustración y la Cuestión Judía" a lo largo de distintas generaciones de intelectuales, no es un decurso necesario y que, por tanto, la interpretación arendtiana de Herder no es una refutación de Lessing vía reductio ad absurdum. En su segundo intercambio epistolar con Jaspers en relación a Rahel Varnhagen, Arendt da una precisión sobre los alcances de su crítica a la Ilustración que resulta esclarecedora. Jaspers le objeta a su antigua estudiante que este libro es injusto con la Ilustración, por el modo en que allí aparece encarnada a través de "ejemplos desfavorables (Dohm, Friedländer) que conducen a una representación peyorativa" ${ }^{49}$. A esto Arendt responde señalando que su intención no fue realizar un balance de la Ilustración in toto, sino en relación al modo en que incidió en la consideración de la cuestión judía en Alemania. Por otra parte, señala una frontera al interior del propio proyecto ilustrado que es crucial para comprender su perspectiva:

En lo que concierne a la Ilustración, quizás este tema se presenta de manera confusa. Lo que me interesaba era sólo la Ilustración en la medida en que era relevante para Rahel en tanto muchacha judía que debía asimilarse (es decir, hacer de manera consciente lo que a otros pudieron conseguir sin esfuerzo). Y en este contexto especial la Ilustración jugó un rol altamente cuestionable. La muestro a

$49 \quad$ H. Arendt y K. Jaspers, Hannah Arendt/Karl Jaspers: Briefwechsel 1926-1969, op. cit., p. 229, carta 134 del 23/08/52. Jaspers agrega que el libro desconsidera la grandeza de la Ilustración tal como esta se presenta en Goethe y en Lessing. En relación a Lessing, en particular, desacuerda con la lectura de Arendt que muestra en qué medida su concepción de la razón se haya de algún modo todavía vinculada a la historia. Sobre esto señala Jaspers: "También en Lessing -gracias a Dios-el origen de la razón es supra histórico y su pensamiento con la historia va más allá de la historia”, idem., bastardillas son nuestras. Esta observación da una idea de la distancia entre Arendt y Jaspers en relación a los sentidos y alcances de la preocupación por concebir una razón históricamente enraizada. través de ejemplos desfavorables porque no hay ejemplos favorables. Decisivo fue Mendelssohn y Friedländer, no Lessing. Y Mendelssohn es -así me parece a diferencia de usted- totalmente chato y oportunista ${ }^{50}$.

En efecto, es a partir de Mendelssohn, que Arendt habla de una "Ilustración entendida a medias y no del todo asumida" $" 51$, la cual Dohm se limita a radicalizar. Al mismo tiempo, afirma que ciertos elementos claves de la filosofía de Lessing no están radicalizados en estos autores sino simplemente falsificados ${ }^{52}$. Además, la generación de judíos asimilados a la que representa Mendelssohn evidencia para Arendt una real pérdida de aquel auténtico pathos ilustrado cuyo origen se remonta a Lessing:

En último término, los judíos excepcionales de Berlín no estaban ni más ni menos asimilados (es decir, reconocidos por la sociedad) que sus padres, quienes habían sido emancipados por el Gran Edicto en tanto que judíos protegidos, esto es, reconocidos por el Estado. Los primeros eran la viva imagen de los segundos, y poco tenían en común con el pathos ilustrado de Lessing o con la lucha por la libertad de la Revolución francesa. La Ilustración y la Revolución se habían derretido entre sus manos, quedando convertidas en un idilio social ${ }^{53}$.

En consonancia con esta pérdida de un pathos ilustrado políticamente activo, la autora nota las distintas actitudes de Lessing y Mendelssohn en relación al mundo político que los rodeaba. Al contrario de Lessing, Mendelssohn es indiferente a la lucha por la conquista de derechos civiles y políticos y con ello da cuenta de que la herencia propiamente política de la Ilustración, vinculada a la lucha por la libertad, queda diluida en su perspectiva $^{54}$. Precisamente porque sostiene una concepción de razón que ha perdido su direccionalidad al mundo humano e histórico en el que esas luchas tienen lugar, Mendelssohn es la bisagra ilustrada hacia la in-

\footnotetext{
Ibidem, p. 235, carta 135 del 07/09/52.

51 H. Arendt, "La Ilustración y la cuestión judía", op. cit., p. 84.

52 Sobre la idea de Mendelssohn como falsificador de ciertas ideas de Lessing, cf. H. Arendt, Rahel Varnhagen, op. cit., p. 33.

53 H. Arendt, "Antisemitismo", op. cit., p. 172.

${ }_{54}$ Arendt señala críticamente esta indiferencia del defensor ilustrado de los judíos hacia su estatus político y civil en términos jurídicos también, mucho después, en Los Orígenes del totalitarismo: "La Prusia que Lessing había descrito como «el más esclavizado país de Europa» era para Mendelssohn «un Estado en el que el más sabio de los príncipes que jamás hayan gobernado a los hombres ha hecho florecer las arte y las ciencias, ha tornado tan extendida a la libertad nacional de pensamiento que sus efectos beneficios alcanzan incluso a los más bajos habitantes de su reino». Tal humilde satisfacción llega a emocionar y a sorprender si se tiene en cuenta que «el más sabio de los príncipes» había hecho muy difícil que el filósofo judío obtuviera permiso de estancia en Berlín [...]. Mendelssohn era incluso consciente de que él, el amigo de toda la Alemania culta, estaría sujeto al mismo gravamen impuesto a un buey que se llevara al mercado, si decidía visitar a su amigo Lavater en Leipzig, pero ni siquiera se le ocurrió ninguna conclusión política relativa al mejoramiento de tales condiciones", H. Arendt, Los orígenes del totalitarismo, trad. S. Catalá y F. J. Lorente, Buenos Aires, Aguilar, 2010, vol. I, pp. 156-57, en nota al pie. Arendt cita aquí el prefacio que Mendelssohn prepara para su traducción de "Rettung der Juden", de Manasseh ben Israel, en M. Mendelssohn, Gesammelte Schriften, Leipzig, Brodhaus, vol. III, p. 180.
} 
trospección romántica ${ }^{55}$. Esta pérdida de direccionalidad lo conduce al Sebstdenken desarraigado, predominante en los salones románticos de la época de Rahel. Sólo para una razón de ese tipo puede "su objeto importar muy poco, igual que a menudo la amada importa menos que el amor", "algo a lo que", agrega Arendt, "dificilmente habría llegado la Ilustración" 56 . Es en Lessing en quien piensa Arendt cuando escribe aquí Ilustración.

Todo esto indica que la autora identifica ciertos aspectos valiosos del proyecto ilustrado tal como este se presenta en Lessing, que no han sido profundizados, sino que han sido abandonados o traicionados, tanto por Mendelssohn y sus sucesores, como por el romanticismo herderiano. "La Ilustración y la Cuestión Judía", así como Rahel Varnhagen, da pocos indicios inequívocos acerca de en qué consistan estos aspectos. Pero a través de un rodeo por otros escritos de la época, es posible sugerir una hipótesis.

Según nuestra lectura, aunque Herder permita iluminar las insuficiencias de la consideración ilustrada de la historia, y en este sentido estricto, Arendt vea una relativa continuidad entre Ilustración y romanticismo, ella no renunciará nunca a la idea ilustrada de que es necesario preservar una "autonomía de la razón frente a la historia", sobre la cual la filosofía herderiana "lleva a cabo una destrucción"57, y a la que Mendelssohn vació de sentido al equiparar "autonomía" a "indiferencia" frente a la historia (del mismo modo que Dohm equipara "autonomía" a "negación" de la historia). La autonomía que, en oposición a estos autores, Arendt revindica no se identificaría con indiferencia o negación, pero permitiría situar a los espectadores del pasado en una posición de comprensión, juicio y, por tanto, libertad frente a los acontecimientos. Se trataría de una autonomía que, como la noción de verdad de Lessing, no nos aparte del mundo de los asuntos humanos, sino que nos "reconduzca a lo humano", y nos permita reconocer allí el "carácter eternamente inacabado y fragmentario" 58 de los esfuerzos humanos por comprender. Sería una autonomía que nos permita situarnos en la historia no para convertirnos en transmisor pasivos de sus fuerzas, sino para actuar ${ }^{59}$. Bajo este horizonte, creemos que pueden entenderse también ciertas alusiones a la idea de humanidad en algunos de sus escritos de intervención en la década posterior. Allí, Arendt sugiere, en sintonía con esta lectura de Lessing, la necesidad de un concepto político de humanidad. Con esta expresión la autora parece sugerir una idea de humanidad que haga lugar a este tipo particular de razón, es decir, una razón que sea capaz de

55 Esta interpretación de la lectura arendtiana de Mendelssohn es defendida también en J. L. Yoder, "The Case of Human Plurality: Hannah Arendt's Critique of Individualism in Enlightenment and Romantic Thinking", Tesis de Maestría, Louisiana State University, 2008, p. 26, https://digitalcommons.1su.edu/gradschool_theses/3155, con acceso el 17/11/1987.

56 H. Arendt, Rahel Varnhagen, op. cit., 29. Bastardillas son nuestras.

57 H. Arendt, "La aparición del principio alemán de Bildung, de Hans Weil”, op. cit., p. 201.

58 H. Arendt, "La Ilustración y la cuestión judía", op. cit., p. 83.

59 La preocupación por una "autonomía frente a la historia" persiste hasta los escritos tardíos de Arendt, donde toma un particular protagonismo: cf. H. Arendt, Conferencias sobre la filosofía política de Kant, trad. C. Corral, Buenos Aires, Paidós, 2003, pp. 18-19. acoger, en su autonomía, la diversidad de historias de todos los pueblos:

Es la gran prerrogativa de la razón el "entender más lenguas de las que habla" y es la gran prerrogativa del hombre ser más que un "modelo de ideas puras". En esa racionalidad y en esa humanidad descansa la garantía filosófica de un concepto político de humanidad ${ }^{60}$.

En suma, un análisis atento de los textos de estos años revela la complejidad de la evaluación arendtiana de las tradiciones filosóficas modernas, e impide lecturas esquemáticas que sugieren, o bien que Arendt se inclina inequívocamente por una de estas tradiciones, o que para la autora ambas, romanticismo e Ilustración, son las caras de una misma moneda. Incluso, también debemos objetar las lecturas que afirman que, echada a rodar, esta "misma moneda" cae inevitablemente en favor del antisemitismo totalitario. Volvemos con esto a una de nuestras preguntas iniciales, aquella sobre el vínculo entre el balance crítico que en los treinta Arendt realiza de la tradición filosófica y su diagnóstico del tiempo presente, marcado por el ascenso del antisemitismo. Pues si bien es cierto que la autora señala la paradoja de que "toda liberación y toda catástrofe experimentada por los judíos europeos ha podido extraer su base teórica y su impulso espiritual de Alemania"61, nunca pretende resolver esta paradoja mostrando la unidad o correspondencia entre las bases teóricas de esa liberación y esa catástrofe, esto es, entre antisemitismo totalitario y las aspiraciones románticoilustradas a la emancipación ${ }^{62}$. Por el contrario, debemos

60 H. Arendt, "Una palabra cristiana sobre la cuestión judía", en Escritos judios, op. cit., p. 239. Bastardillas son nuestras. El escrito es de 1942. Significativamente, el fragmento citado viene luego de la recomendación enfática de un capítulo de Ransoming the Time, Nueva York, Scribner's, 1941, de Jacques Maritain, en donde el filósofo católico retoma una idea que para Arendt tiene fuerte impronta lessingniana: el llamado a entender la idea de tolerancia entre los pueblos como "amistad cívica". Arendt cita con comillas la página 118 de este libro (en relación a cuyo autor, sin embargo, guarda importantes diferencias). Sobre la idea de amistad cívica en Lessing, Arendt escribirá en 1959 en "Sobre la humanidad en tiempos de oscuridad. Reflexiones sobre Lessing", Hombres en tiempos de oscuridad, Barcelona, Gedisa, 1990, pp. 13-43. En un sentido similar al de este fragmento, también rescatando una idea política de humanidad, se expresan los siguientes pasajes, también de 1942: "La idea de una desigualdad fundamental y natural entre los pueblos, que es la forma que la injusticia ha adoptado en nuestro tiempo, solamente se puede derrotar con la idea de una igualdad original e inalienable entre todos aquellos que muestran un semblante humano", H. Arendt, "La retórica del diablo", en Escritos judios, op. cit., p. 234. "Nosotros, los judíos patriotas, $[\ldots]$ nos aliamos con aquel que directa o indirectamente nos ayude a erradicar la locura de la superioridad racial y a restaurar la humanidad [Humanität], la solidaridad del género humano [Menschengeschlecht]", H. Arendt, "Pro Paul Tillich", en Escritos judios, op. cit., p. 248.

61 H. Arendt, "Antisemitismo", op. cit., 139. Bastardillas son nuestras. La misma idea expresada en otras palabras: "Ninguna otra nación en la historia mundial reciente ha infringido tanta desgracia sobre los judíos como Alemania. [...] [Al mismo tiempo que] En ningún otro lugar se rindió un servicio mayor para la liberación de los judíos como en la misma Prusia, donde, desde Lessing a Wilhelm von Humboldt, la cuestión judía y la emancipación judía fueron equiparadas con la lucha por la libertad humana y la justicia universa", pues, continúa: "ninguna lucha por la liberación de los judíos en Europa ha dejado de extraer su fuerza espiritual de Lessing y sus argumentos de Dohm”, ibidem, pp. 138-139.

62 En particular, es importante notar que para Arendt la asociación entre romanticismo y nacionalismo, y la variante antisemita de éste, no im- 
interpretar que, desde su perspectiva, Ilustración y romanticismo contribuyen de distintas maneras a la frustración de aspiraciones ilustradas y con ello a crear -aunque no a producir-, las condiciones en las cuales los judíos quedarán inermes frente al ascenso del movimiento totalitario. Con todo, Arendt no está dispuesta a desestimar sin más esas aspiraciones frustradas: centralmente la promesa ilustrada de autonomía frente a la historia y, asociada a esta, una idea política de humanidad que afirme la igualdad de todos los pueblos ${ }^{63}$. Aunque por caminos sinuosos y vacilantes, buscará para ellas nuevos sentidos y bases ${ }^{64}$.

\section{Consideraciones finales}

Las notas precedentes se proponen como una contribución a la comprensión del vínculo entre las reflexiones de Arendt sobre el judaísmo, y su posición crítica de la modernidad filosófica en los tempranos 30. Con este mismo espíritu, pero en otra línea de argumentación, Ricardo Forster, siguiendo el marco de lectura propuesto por Reyes Mate, ha encontrado en "La Ilustración y la Cuestión Judía" una temprana crítica a la racionalidad universal de la Ilustración desde el punto de vista de la marginalidad que representa la condición judía ${ }^{65}$. Para finalizar, quisiéramos señalar que, si bien este escrito arendtiano presenta una crítica a la Ilustración a la luz de su fracaso en relación a la cuestión judía, no debiera pasarse por alto los sentidos en que se distingue de otras críticas contemporáneas con las cuales este intérprete lo asocia.

La forma paradigmática de la línea en la que Forster inscribe a Arendt se encuentra en Franz Rosenzweig y sus continuadores más relevantes son Walter Benjamin

plicará una asociación directa entre romanticismo y totalitarismo antisemita. Ya en 1932, Arendt impugna los intentos por apropiar en clave nacional-socialista un clásico romántico político como Adam Müller. Cf. H. Arendt, “Adam Müller ¿Renacimiento?”, en Más allá de la filosofia: escritos sobre cultura, arte y literatura, op. cit., pp. 189-97. Posteriormente, la autora destacará que una de las contribuciones del romanticismo a los orígenes del totalitarismo fue la idea de "personalidad innata", y la idea de "genio", las cuales, sin embargo, no deben sobrevalorarse ni aislarse de su combinación con otros factores. Cf. H. Arendt, Los orígenes del totalitarismo, op. cit., vol. I, p. 332.

63 Enzo Traverso ha señalado que el gesto de rescate de la Ilustración, más allá de sus aporías y en contra del creciente antisemitismo, que hemos intentado mostrar en Arendt, era común entre muchos de los judíos alemanes que se vieron obligados a emigrar desde 1933, y quienes, en sus intervenciones intelectuales, "se consideraban de alguna manera depositarios de la misión de perpetuar la tradición de la Aufklärung que el nazismo estaba destruyendo", E. Traverso, El final de la modernidad judia, op. cit., p. 53. El autor propone como ejemplo, la publicación en 1936 de W. Benjamin, Personajes alemanes, Barcelona, Paidós Ibérica - ICE Universidad Autónoma de Barcelona, 1995, que reúne cartas de un conjunto de ilustrados alemanes.

64 En una investigación todavía en curso, nos proponemos indagar el devenir de la reflexión sobre una idea política de humanidad, de impronta ilustrada, en el pensamiento de Arendt en las décadas posteriores. En los años cuarenta, otro filósofo ilustrado comienza a tomar preeminencia en relación a este tópico: Immanuel Kant, cuya idea de humanidad juega un papel importante en Los orígenes del totalitarismo.

65 R. Forster, "El último movimiento mesiánico", op. cit., p. 371 y ss. Foster sigue la perspectiva general de recuperación de la óptica judía para pensar las insuficiencias del proyecto ilustrado que propone Reyes Mate en Memoria de Occidente. Actualidad de pensadores judios olvidados, op. cit. y Emmanuel Levinas, aunque también sugiere que en cierta medida La Dialéctica de la Ilustración, de Theodor Adorno y Max Horkheimer la representan. El núcleo de esta perspectiva consiste en el señalamiento de que "El mecanismo de construcción de la universalidad -ese proceso histórico que gira alrededor de la filosofía de la Ilustración y que se vale de una radical abstracción para generar las condiciones de un nuevo postulado de lo humano- tiene su presupuesto, su punto de partida y su proyección en la lógica de la exclusión"66. Siguiendo a Reyes Mate, para el autor la marginalidad de lo judío es el más vivo testimonio de este movimiento de exclusión. Con Mate, Foster afirma que lo que la óptica del pensador judío viene entonces a revelar desde su marginalidad, es el carácter excluyente, negador de la particularidad y la diferencia en tanto otredad, intrínseco a la universalidad abstracta de la razón Ilustrada.

Sin embargo, el abordaje arendtiano de la relación entre Ilustración y cuestión judía no puede interpretarse estrictamente en esta clave. Para Arendt lo que lo que la marginalidad del judío revela no es el carácter intrínsecamente excluyente de la razón ilustrada, sino su imposibilidad de pensar la historia como tal, esto es, para la autora, la historia en su particularidad y contingencia, en su calidad de producto de la acción y desde el punto de vista de los actores-espectadores que se sitúan en un presente particular. Esta diferencia no es menor. En los escritos judíos de la autora no encontramos un rescate de una racionalidad judía no abstracta, o de los sentidos que el judaísmo es capaz de afirmar frente a la negación ilustrada de la diferencia, sino una recuperación, y un llamado a recuperar, ejercicios de comprensión histórica que abrevan en fuentes diversas. Esto implica que Arendt no afirma el valor intrínseco de la singularidad de la historia judía como tal o la sabiduría sedimentada en sus particulares experiencias, sino que reclama el derecho y la responsabilidad de los judíos a pensar(se) históricamente, responsabilidad que, por otra parte, es común a todos los pueblos, en tanto llevan una existencia política. Esto no quiere decir que Arendt no encuentre en la tradición judía perspectivas y horizontes para una crítica de la realidad política y la filosofía política, tal como lo sugiere "La Tradición Oculta" ${ }^{67}$ (en esta línea, se puede indagar, por ejemplo, si la experiencia de la diáspora es una fuente de su crítica al Estado-Nación, tal como ha sugerido Natan Sznaider ${ }^{68}$ ). Pero, como hemos intentado mostrar, se trata menos de hacer del judaísmo la prueba negativa de un fatal "defecto de origen" de la Ilustración ${ }^{69}$ y la fuente positiva para su superación, que

\footnotetext{
66 R. Forster, "El último movimiento mesiánico", op. cit., p. 360.

67 H. Arendt, "La tradición oculta", en Escritos judios, op. cit., pp. 36698.

68 N. Sznaider, La memoria judía y el orden cosmopolita, op. cit.

69 R. Mate, Memoria de Occidente, op. cit., p. 16. Por otra parte, en relación a la memoria de los vencidos que, según Foster, tanto Arendt como Benjamin y Rosenzweig parecen afirmar, en una especie de común "crítica anamnética" de la Ilustración, también existen diferencias significativas. En particular, encontramos ausente en Arendt, el rasgo "salvífico" y utópico propio de el cariz mesiánico, que tanto Forster como Reyes Mate atribuyen a esta "razón anamnética". Cf. ibidem., p. 24.
} 
de recuperar la Ilustración contra sí misma a la luz del fracaso de sus propias pretensiones.

El balance arendtiano de las raíces teórico-filosóficas del desentendimiento judío en relación a la historia tiene como resultado no un juicio final sobre las tradiciones filosóficas del XVIII, sino el emprendimiento de una búsqueda que permanecerá en el terreno abierto por las mejores intuiciones de estas tradiciones, en particular, ciertas intuiciones ilustradas, aunque esta exploración conducirá a la autora a sus recovecos menos visitados, sus reveces y líneas discontinuadas. La base de esta búsqueda es la constatación de que la pérdida de la comprensión histórica es una pérdida política catastrófica.
Un interrogante aparece en estos años y a partir de entonces, queda para Arendt suspendido sobre el campo filosófico sin resolución: ¿qué tipo de pensar filosófico es capaz de dar cuenta de la dignidad humana no a pesar, ni más allá de, sino a través y en la historia? $\mathrm{O}$, dicho de otra manera: ¿cómo concebir filosóficamente una razón histórica capaz de devolvernos al mundo político? De este modo se inicia la búsqueda de una forma de comprender el pensamiento como una singular autonomía frente a la historia, a igual distancia de su destrucción romántica, que del "pensar por sí mismo", desarraigado y desmundaneizante, de la Ilustración.

\section{Bibliografía}

Arendt, H., “Adam Müller ¿Renacimiento?” (pp. 189-197); “La aparición del principio alemán de Bildung de Hans Weil” (pp. 198-205), en H. Arendt, Más allá de la filosofía: escritos sobre cultura, arte y literatura, trad. E. Rubio García, Madrid, Trotta, 2014.

-, “Aufklärung und Judenfrage”, Zeitschrift für die Geschichte der Juden in Deutschland 4, 1932, pp. 65-77.

-, Conferencias sobre la filosofía politica de Kant, trad. C. Corral, Buenos Aires, Paidós, 2003.

-, Diario filosófico, 1950-1973, U. Ludz e I. Nordmann (eds.), trad. R. Gabás, Barcelona, Herder, 2006.

-, La condición humana, trad. R. Gil Novales, Buenos Aires, Paidós, 2009.

-, "La Ilustración y la cuestión judía” (pp. 79-96); “Antisemitismo” (pp. 122-195); "La retórica del diablo” (pp. 233-234); "Una palabra cristiana sobre la cuestión judía” (pp. 238-240); "Pro Paul Tillich” (pp. 246-248); "La tradición oculta” (pp. 366-98); "Una revisión de la historia judía" (394-403); "Las enseñanzas de la historia” (pp. 404-408), en J. Kohn y R. H. Feldman (eds.), Escritos judios, trad. M. Cancel, V. Gómez Ibáñez y E. Cañas, Madrid, Paidós, 2009.

-, Los orígenes del totalitarismo, trad. S. Catalá y F. J. Lorente, vols. I y II, Buenos Aires, Aguilar, 2010.

-, "Privileged Jews", Jewish Social Studies 1, vol. 8, 01/1946, pp. 3-30.

-, Rahel Varnhagen: vida de una mujer judia, trad. D. Najmías, Barcelona, Lumen, 2000.

-, "Sobre la humanidad en tiempos de oscuridad. Reflexiones sobre Lessing", en Hombres en tiempos de oscuridad, Barcelona, Gedisa, 1990, pp. 13-43.

-, The Jew as a Pariah: Jewish Identity and Politics in the Modern Age, R. H. Feldman (ed.), Nueva York, Grove Press, 1978.

-, The Jewish Writings, J. Kohn y R. H. Feldman (eds.), Nueva York, Schocken Books, 2007.

-, y Jaspers, K., Hannah Arendt/Karl Jaspers: Briefwechsel 1926-1969, L. Köhler y H. Saner (eds.), Munich-Zúrich, Piper, 1993.

Benhabib, S., "The Pariah and Her Shadow: Hannah Arendt's Biography of Rahel Varnhagen”, en The reluctant modernism of Hannah Arendt, Lanham-Boulder-Nueva York, Rowman \& Littlefield Publishers, 2003, pp. 1-34.

Benjamin, W., El concepto de crítica del arte en el romanticismo alemán, Madrid, Península, 1988.

-, Personajes alemanes, Barcelona, Paidós Ibérica - ICE Universidad Autónoma de Barcelona, 1995.

Bernstein, R., Hannah Arendt and the Jewish Question, Cambridge, Mit Press, 1996.

Della Bianchina, A., "Kultur versus Bildung: amicizia e resistenza in Hannah Arendt", Studi sulla Formazione/Open Journal of Education 1, vol. 19, 2016, pp. 143-153.

von Dohm, C. W., Über die bürgerliche Verbesserung der Juden, Göttingen, Wallstein, 2015.

Forster, R., "El último movimiento mesiánico", en D. Tatián y R. Forster, Mesianismo, nihilismo y redención: de Abraham a Spinoza, de Marx a Benjamin, Buenos Aires, Altamira, 2005, pp. 337-510.

Gundolf, F., Romantiker, Berlín-Wilmersdorf, Keller, 1930.

-, Romantiker. Neue Folge, Berlín-Wilmersdorf, Keller, 1931.

Friedländer, D., Sendschreiben einiger jüdischer Hausväter, Nürenberg, Rawschen Buchhandlung, 1800.

Hunziker, P., "Rahel Varnhagen y las tentaciones del intelectual romántico", en Filosofía, política y platonismo. Una investigación sobre la lectura arendtiana de Kant, Buenos Aires, Prometeo, 2018, pp. 35-39.

Herder, J. G., Ideas para una Filosofía de la Historia de la Humanidad, trad. J. Rovira Armengol, Buenos Aires, Losada, 1959.

-, Ensayo sobre el origen del lenguaje. Otra filosofía de la historia para la educación de la humanidad. Ideas para la filosofía de la historia de la humanidad (selec.). Una metacrítica de la Crítica de la razón pura, trad. P. Ribas y V. López-Domínguez, Madrid, Gredos, 2015.

-, “Erläuterung zum Neuen Testament” (vol. XI); “Adrastea” (vol. X), en Sämmtliche Werke, Stuttgart-Tübingen, Gotta'sche Buchhandlung, 1829.

Humboldt von, W., Wilhelm von Humboldt und Karoline von Humboldt in ihren Briefen, Anna von Sydow (ed.), Berlín, 1900 , vol. V.

Keedus, K., "«The flight into the self»: Arendt on romanticism”, en The Crisis of German Historicism: The Early Political Thought of Hannah Arendt and Leo Strauss, Cambridge, Cambridge University Press, 2015, pp. 53-62.

King, R. H., "On Race and Culture. Hannah Arendt and her contemporaries", en S. Benhabib (ed.), Politics in dark times: Encounters with Hannah Arendt, Cambridge, Cambridge University Press, 2010, pp. 113-34. 
Löwy, M., "Hannah Arendt y Walter Benjamin”, en Judios Heterodoxos. Romanticismo, mesianismo, utopía, Barcelona, Anthropos, 2015, pp. 59-70.

Leibovici, M., “Arendt's Rahel Varnhagen: a New Kind of Narration in the Impasses of German-Jewish Assimilation and Existenzphilosophie", Social Research: An International Quarterly 3, vol. 74, 2007, pp. 903-922.

Lessing, G. E., "Eine Duplik"; "Anti-Goeze"; "Über den Beweis des Geistes und der Kraft"; "Die Erziehung des Menschengeschlechts”, en K. Lachmann (ed.), Sämmtliche Schriften. Neue rechtmäßige Ausgabe, vol. X, Berlin, Voß’schen Buchhandlung, 1839.

-, Fragmente eines Ungennanten, Hamburgo, Gernot Fligge, s/f. Disponible en: https://www.hs-augsburg.de/ harsch/ germanica/Chronologie/18Jh/Reimarus/rei_fr00.html (accedido el 20/06/2020).

-, La educación del género humano, Barcelona, Azul, 2008.

Maritain, J., Ransoming the Time, Nueva York, Scribner's, 1941.

Mate, R., Memoria de Occidente. Actualidad de pensadores judios olvidados, Barcelona, Antrophos, 1997.

Mendelssohn, M., "Jerusalem, oder über Religöse Macht und Judentum" (vol. I), "Vorrede" a "Rettung der Juden" de Manasseh ben Israel; y "Briefwechsel mit Bonnet” (vol. III), en Gesammte Schriften, Leipzig, Brodhaus, 1845, y III.

Schmitt, C., Romanticismo Político, Buenos Aires, Universidad Nacional de Quilmes, 2005.

Scholem, G., Major Trends in Jewish Mysticism, Nueva York, Schocken Books, 1961.

Sznaider, N., La memoria judia y el orden cosmopolita, Buenos Aires, Capital Intelectual, 2012.

Traverso, E., El final de la modernidad judia: historia de un giro conservador, Buenos Aires, Fondo de Cultura Económica, 2014.

Weil, H., Die Entstehung des deutschen Bildungsprinzip. Schriften zur Philosophie und Soziologie, Bonn, Friedrich Cohen, 1930.

Young-Bruehl, E., Hannah Arendt: una biografia, Barcelona, Paidós, 2006.

Yoder, J. L., "The Case of Human Plurality: Hannah Arendt's Critique of Individualism in Enlightenment and Romantic Thinking”, Tesis de Maestría, Louisiana State University, 2008, https://digitalcommons.lsu.edu/gradschool_theses/3155 (accedido el 20/12/2019). 